\title{
TARIF, KESADARAN DAN SOSIALISASI PAJAK TERHADAP PENINGKATAN PENERIMAAN PAJAK MELALUI KEPATUHAN WAJIB PAJAK SEBAGAI VARIABEL INTERVENING
} (Implementasi PP 23 Tahun 2018)

\author{
Walid Rudianti ${ }^{1}$, Veny Dwi Endarista ${ }^{2}$ \\ STIE Tamansiswa Banjarnegara Jl. Mayjend Panjaitan No. 29 Banjarnegara \\ Email: walidrudianti90@gmail.com ${ }^{1}$, venyendarista2016@gmail.com ${ }^{2}$
}

\begin{abstract}
This research is motivated by several things. In 2019 the UMKM tax sector is still far below the target (PP 23 is not very influential) and observations that researchers have made in the Banjarnegara District area, show that many MSME do not know about the implementation of the new PP 232018 tariff. This research method uses quantitative methods with data collection techniques through distributing questionnaires. Sampling was done by using simple random sampling technique. Hypothesis testing uses regression analysis of mediating variables with the causal step method. The results showed that partially the tariff has a significant positive effect on increasing tax revenue. awareness does not have a significant positive effect on increasing tax revenue and tax socialization has a significant positive effect on increasing tax revenue. Furthermore, tariffs have a significant positive effect on taxpayer compliance, awareness has a significant positive effect on taxpayer compliance and tax socialization does not have a significant positive effect on taxpayer compliance. then taxpayer compliance has a significant positive effect on increasing tax revenue. for taxpayer compliance mediates the relationship between rates and increased tax revenue. Taxpayer compliance does not mediate the relationship between taxpayer awareness and increased tax revenue. and taxpayer compliance mediates the relationship between tax socialization and increased tax revenue.
\end{abstract}

Keywords: Tax rates, awareness, tax socialization, taxpayer compliance, and increased tax revenue.

\section{PENDAHULUAN}

\section{Latar belakang}

Pajak merupakan hal yang penting bagi negara-negara di dunia karena pajak merupakan sumber penghasilan utama bagi sebagian besar negara di dunia. Dengan adanya realisasi penerimaan pajak pula pembiayaan pembangunan, hutang negara dan pengeluaran pemerintah lainnya dapat dibiayai.

Sebagai sumber utama pendapatan Negara, pemerintah terus melakukan berbagai upaya untuk meningkatkan penerimaan pajak. Reformasi pajak adalah salah satu upaya yang dilakukan dalam rangka meningkatkan jumlah penerimaan pajak. Beberapa sumber pajak berasal dari usaha yang dijalankan oleh negara tersebut, juga pelaku usaha yang ada pada daerah yang terus bertumbuh dan berkembang maju. UMKM merupakan bagian dari penyumbang pajak di Indonesia. Dengan jumlah UMKM yang cukup besar yaitu lebih dari 64 juta. Untuk terus mewujudkan target pendapatan negara terutama dari sektor pajak, pemerintah terus mengkaji aturan-aturan 
mengenai pajak salah satunya dengan peraturan perundang-undangan mengenai pajak UMKM PP No.23 tahun 2018. Pada 1 Juli 2018, pemerintah telah menerbitkan kebijakan baru terkait perpajakan. Kebijakan tersebut adalah Peraturan Pemerintahan atau PP Nomor 23 Tahun 2018 tentang Pajak Penghasilan atas Penghasilan dari Usaha yang Diterima atau Diperoleh Wajib Pajak yang Memiliki Peredaran Bruto Tertentu.

Peraturan ini diterbitkan untuk menggantikan peraturan sebelumnya yakni PP Nomor 46 Tahun 2013 yang dinilai memiliki sejumlah kekurangan, sehingga perlu disesuaikan dengan kondisi perekonomian terkini. Hal yang paling menjadi sorotan adalah perubahan pengenaan tarif $\mathrm{PPh}$ Final dari yang semula $1 \%$ menjadi $0,5 \%$.

Mengutip kompas.com Menteri Keuangan Sri Mulyani Indrawati menilai, realisasi penerimaan pajak Usaha Mikro, Kecil, dan Menengah (UMKM) semester 12018 masih terlampau rendah. Sebagai harapan dengan diturunkannya pajak penghasilan $(\mathrm{PPh})$ final UMKM dari 1 persen menjadi 0,5 persen dapat meningkatkan tingkat kepatuhan wajib pajak. Sebagai Informasi, pemerintah telah menurunkan tarif bagi pelaku UMKM menjadi 0,5 persen dari sebelumnya 1 persen terhadap penghasilan. Hal ini tertuang dalam PP Nomor 23 Tahun 2018. Wajib Pajak UMKM dalam ketentuan ini adalah pengusaha dengan peredaran bruto atau omzet sampai dengan Rp.4,8 miliar per tahun.

Di Kecamatan Banjarnegara sendiri, peneliti melakukan observasi melalui wawancara dengan beberapa pelaku UMKM. Setelah penulis melakukan wawancara terhadap 15 pelaku
UMKM penulis dapat menyimpulkan bahwa dengan penurunan tarif dari $1 \%$ menjadi $0,5 \%$ menjadikan para pelaku UMKM tidak merasa terbebani akan besarnya pembayaran bulanan. Beberapa dari pelaku UMKM mengaku telah melakukan pembayaran pajak rutin setiap bulan terbukti dari laporan SPT dan bukti pembayaran yang ada baik sebelum adanya penurunan tarif atau sesudah penurunan tarif.

Namun tidak sedikit pula yang memberi keterangan bahwa mereka belum mengetahui adanya terbitan PP 23 pengganti PP 46 karena tidak adanya sosialisasi secara menyeluruh dan intens yang mengena kepada masyarakat. Di sisi lain, yang mendasari mereka membayar pajak adalah kepemilikan NPWP (Nomor Pokok Wajib Pajak ) yang aktif dan penagihan dari kantor pajak, bukan karena sadar kewajiban dan paham kewajiban yang harus dilaksanakan sebagai pemilik NPWP terdaftar.

Hingga Juli 2019 baru 67,2 persen atau baru sebesar 12,3 juta dari jumlah Wajib Pajak yang wajib menyampaika SPT sebanyak 18,3 juta. Terkait dengan ini, menurut penilaian Ditjen Pajak Angin Prayitno Aji mengatakan bahwa insentif bagi usaha mikro kecil dan menengah (UMKM), yang maih jauh dari ekspektasi otoritas pajak. (Bissniss.com 2019).

Helmi Sularsih (2018) dalam jurnalnya berkesimpulan bahwa penerapan tarif PP 23 Tahun 2018 berpengaruh terhadap peningkatan penerimaan pajak UMKM Kota Malang. Pada penelitian yang dilakukan oleh Sintia Triola (2019) yang menunjukkan bahwa tarif pajak PPh 23 Tahun 2018 belum sepenuhnya meningkatkan penerimaan $\mathrm{PPh}$ final pasal 4 ayat (2) disebabkan karena kurangnya informasi dan 
kesadaran Wajib Pajak akan pajak yang masih terbilang lemah.

Penelitian yang dilakukan oleh Manik Asri (2009) menemukan bahwa kesadaran Wajib Pajak berpengaruh positif pada pelaporan kepatuhan wajib pajak. Jika kesadaran Wajib Pajak meningkat, maka kepatuhan Wajib Pajak akan meningkat juga dengan hasil penerimaannya (Nugroho, 2006). Sementara itu, dalam jurnal Marisa Herryanto dan Agus Arianto Toly (2013) penelitian ini membuktikan pengujian secara parsial bahwa kesadaran Wajib Pajak berpengaruh negatif terhadap penerimaan pajak penghasilan di KPP Pratama Surabaya Sawahan.

Dalam penelitian Suyanto dan Kiftia Yahya (2016) berdasarkan alisis data dan pengujian hipotesis disimpulkan bahwa variabel sosialisasi perpajakan berpengaruh positif signifikan terhadap variabel penerimaan pajak penghasilan orang pribadi. Afria Setiawati (2017) dalam jurnalnya menyatakan bahwa variabel sosialisasi perpajakan tidak berpengaruh terhadap peningkatan penerimaan pajak.

Atas uraian di atas, maka peneliti melakukan penelitian atau menguji Tarif, Kesadaran, Sosialisasi Terhadap Peningkatan Penerimaan Pajak Melalui Kepatuhan Wajib Pajak Sebagai Variabel Intervening (Implementasi PP 23 Tahun 2018).

\section{Rumusan Masalah}

1. Apakah tarif pajak berpengaruh terhadap peingkatan penerimaan pajak?

2. Apakah kesadaran berpengaruh terhadap peningkatan penerimaan pajak?
3. Apakah sosialisasi berpengaruh terhadap peningkatan penerimaan pajak?

4. Apakah tarif pajak berpengaruh terhadap kepatuhan Wajib Pajak?

5. Apakah kesadaran berpengaruh terhadap kepatuhan Wajib Pajak?

6. Apakah sosialisasi pajak berpengaruh terhadap kepatuhan Wajib Pajak?

7. Apakah kepatuhan Wajib Pajak berpengaruh terhadap peningkatan penerimaan pajak?

8. Apakah tarif pajak berpengaruh terhadap peningkatan penerimaan pajak melalui kepatuhan Wajib Pajak?

9. Apakah kesadaran berpengaruh terhadap peningkatan penerimaan pajak melalui kepatuhan Wajib Pajak?

10. Apakah sosialisasi pajak berpengaruh terhadap peningkatan penerimaan pajak melalui kepatuhan Wajib Pajak?

\section{Tujuan Penelitian}

Tujuan dari penelitian ini adalah:

1. Untuk mengetahui apakah tatif pajak berpengaruh terhadap peningkatan penerimaan pajak.

2. Untuk mengetahui apakah kesadaran berpengaruh terhadap peningkatan penerimaan pajak.

3. Untuk mengetahui apakah sosialisasi pajak berpengaruh terhadap peningkatan penerimaan pajak.

4. Untuk mengetahui apakah tarif pajak berpengaruh terhadap kepatuha Wajib Pajak.

5. Untuk mengetahui apakah kesadaran berpengaruh terhadap kepatuhan Wajib Pajak.

6. Untuk mengetahui apakah sosialisasi pajak berpengaruh terhadap kepatuhan Wajib Pajak. 
7. Untuk mengetahui apakah kepatuhan Waji Pajak berpengaruh terhadap peningkatan penerimaan pajak.

8. Untuk mengetahui apakah tarif pajak berpengaruh terhadap peningkatan penerimaan pajak melalui kepatuhan Wajib Pajak.

9. Untuk mengetahui apakah kesadaran berpengaruh terhadap peningkatan penerimaan pajak melalui kepatuhan Wajib Pajak.

10. Untuk mengetahui apakah sosialisasi pajak berpengaruh terhadap peningkatan penerimaan pajak melalui kepatuhan Wajib Pajak.

\section{METODE PENELITIAN}

\section{Lokasi Penelitian}

Penelitian ini dilakukan di Kecamatan Banjrnegara Provinsi Jawa Tengah.

\section{Jenis Penelitian}

Penelitian ini menggunakan data kuantitatif.

\section{Variabel Penelitian}

a. Variabel bebas: Tarif (X1), Kesadaran (X2), Sosialisai (X3).

b. Variabel terikat: Peningkatan Penerimaan PajakDae (Y).

c. Variabel Intervening: Kepatuhan Wajib Pajak (M).

\section{Definisi Konsep dan Definisi Operasional Variabel}

a. Peningkatan Penerimaan Pajak

Definisi Konsep: Definisi penerimaan pajak menurut John Hutagaol (2011) adalah penerimaan pajak merupakan sumber penerimaan yang yang dapat diperoleh secara terus menerus dan dapat dikembangkan secara optimal sesuai kebutuhan pemerintah serta kondisi masyarakat.
Definisi Operasional: Penerimaan pajak adalah penghasilan yang diperoleh oleh pemerintah atau negara yang bersumber dari pajak rakyat.

Indikator: Kesadaran, kepatuhan, tarif, dan sosialisasi pajak.

b. Kepatuhan Wajib Pajak

Definisi Konsep: Kepatuhan wajib pajak merupakan suatu ketaatan untuk melakukan ketentuan ketentuan atau aturan-aturan perpajakan yang diwajibkan atau diharuskan untuk dilaksanakan (Divianto, 2013).

Definisi Operasional: Sebuah kondisi dimana meningkatnya pendapatan Suatu tindakan yang mencerminkan pemenuhan kewajiban mebayar pajak dan melakukan pelaporan SPT tahunan sebagai wajib pajak.

Indikator: Kepatuhan mendaftarkan diri ke kantor pajak, kepatuhan dalam menghitung dan memperhitungkan pajak oleh WP, kepatuhan membayar pajak dilakukan sendiri oleh WP, dan kepatuhan pelaporan sendiri oleh WP.

c. Tarif

Definisi Konsep: Menurut Aliminsyah, dkk dalam buku Kamus Istilah Akuntansi mendefinisikan tarif sebagai pengaturan yang sistematik dari bea yang dipungut atas barang dan jasa yang melewati batas-batas negara.

Definisi Operasional: Tarif pajak merupakan dasar pengenaan pajak atas objek pajak yang menjadi tanggung jawab wajib pajak yang telah disepakati perhitungannya.

d. Kesadaran

Definisi Konsep: Pajak Kesadaran wajib pajak menurut 
Nasution (2013) menyatakan bahwa kesadaran wajib pajak merupakan sikap wajib pajak yang memahami dan mau melaksanakan kewajibannya untuk membayar pajak dan telah melaporkan semua penghasilannya tanpa ada yang disembunyikan sesuai dengan ketentuan yang berlaku.

Definisi Operasional: Kesadaran wajib pajak akan perpajakan adalah rasa yang timul dari dalam diri wajib pajak atas kwajibannya membayar dengan ikhlas tanpa adanya unsur pakaaan.

Indikator: Mengetahui adanya undang-undang dan ketentuan perpajakan, mengetahui fungsi pajak untuk pembiayaan negara, memahami bahwa kewajiban perpajakan harus dilaksanakan sesuai dengan ketentuan yang berlaku, memahami fungsi pajak untuk pembiayaan negara, menghitung, membayar, melaporkan pajak dengan suka rela dan menghitung, membayar, melaporkan pajak dengan benar.

e. Sosialisasi Perpajakan

Definisi Konsep: Menurut Rohmawati, Prasetyono, Rimawati (2013), sosialisasi perpajakan adalah upaya yang dilakukan oleh Dirjen Pajak untuk memberikan sebuah pengetahuan kepada masyarakat dan khususnya Wajib Pajak agar mengetahui tentang segala hal mengenai perpajakan baik peraturan maupun tata cara perpajakan melalui metode-metode yang tepat.

Definisi Operasional: Suatu upaya dan proses memberikan informasi perpajakan untuk menghasilkan perubahan pengetahuan, agar tergolong faham dan berkontribusi dalam melaksanakan kewajiban perpajakan

Indikator: penyuluhan langsung dan penyuluhan tidak langsung.

\section{Populasi Sampel dan Teknik Sampel}

a. Populasi Penelitian

Populasi dalam penelitian ini adalah pelaku UMKM Kecamatan Bnajarnegara yang berjumlah 203 pelaku UMKM pada tahun 2019.

b. Teknik Sampel

Teknik pengambilan sampel dalam penelitian ini menggunakan teknik simple random sampling.

c. Sampel Penelitian

Untuk mencari jumlah sampel penelitian, peneliti menggunakan rumus slovin. Jumlah populasi yang akan diteliti adalah 203 pelaku UMKM dan tingkat kesalahan yang dikehendaki adalah 5\%. Maka sampel yang digunakan adalah:

$$
\begin{aligned}
& n=\frac{N}{1+N e^{2}} \quad \text { Keterangan : } \\
& =\frac{203}{1+\left(203 \times(5 \%)^{2}\right)} \quad \begin{array}{ll}
\mathrm{N}=\text { Sampel } \\
\mathrm{N}=\text { Populasi }
\end{array} \\
& =\frac{203}{1+\left(203 \times 0,05^{2}\right)} \\
& =\frac{203}{1+(203 \times 0,0025)}=\frac{203}{1,5075}=134,660033167=\underline{135}
\end{aligned}
$$

\section{Teknik Analisis Data}

Adapun teknik analisis data yang digunakan dalam penelitian ini adalah

1. Uji Instrumen, terdiri dari :

a. Uji Validitas

b. Uji Reliabilitas

2. Uji Asumsi Klasik, terdiri dari :

a. Uji Normalitas

b. Uji Multikolonieritas

c. Uji Heterokedastisistas

3. Uji ketepatan model, terdiri dari : 
a. Koefisien Determinasi (R2)

b. Uji T statistik

\section{Uji Hipotesis}

Pada penelitian ini menggunakan menggunakan Analisis Regresi Variabel Mediasi dengan Metode Kausal Step.

\section{HASIL DAN PEMBAHASAN}

\section{Uji Instrumen}

\section{a. Uji Validitas}

\begin{tabular}{|c|c|c|c|c|c|c|}
\hline $\begin{array}{l}\mathrm{N} \\
\mathrm{o}\end{array}$ & $\begin{array}{l}\text { Vari } \\
\text { abel }\end{array}$ & $\begin{array}{c}\mathrm{r} \\
\text { hitung }\end{array}$ & $\begin{array}{c}\mathrm{r} \\
\text { tabel }\end{array}$ & $\begin{array}{c}\text { Sig } \\
\text { hitung }\end{array}$ & $\begin{array}{c}\text { Sig } \\
\text { tabel }\end{array}$ & $\begin{array}{c}\text { Ketera } \\
\text { ngan }\end{array}$ \\
\hline & $\begin{array}{l}\text { Tari } \\
\mathrm{f}\end{array}$ & & & & & \\
\hline 1 & $\mathrm{X}_{1.1}$ & 0,756 & $\begin{array}{l}0,30 \\
6\end{array}$ & 0,000 & $\begin{array}{l}0,05 \\
0\end{array}$ & Valid \\
\hline 2 & $\mathrm{X}_{1.2}$ & 0,837 & $\begin{array}{l}0,30 \\
6\end{array}$ & 0,000 & $\begin{array}{l}0,05 \\
0\end{array}$ & Valid \\
\hline 3 & $\mathrm{X}_{1.3}$ & 0,747 & $\begin{array}{l}0,30 \\
6\end{array}$ & 0,000 & $\begin{array}{l}0,05 \\
0\end{array}$ & Valid \\
\hline 4 & $\mathrm{X}_{1.4}$ & 0,475 & $\begin{array}{l}0,30 \\
6\end{array}$ & 0,000 & $\begin{array}{l}0,05 \\
0\end{array}$ & Valid \\
\hline 5 & $\mathrm{X}_{1.5}$ & 0,678 & $\begin{array}{l}0,30 \\
6 \\
\end{array}$ & 0,000 & $\begin{array}{l}0,05 \\
0\end{array}$ & Valid \\
\hline $\begin{array}{l}\mathrm{N} \\
\mathrm{o}\end{array}$ & $\begin{array}{l}\text { Vari } \\
\text { abel }\end{array}$ & $\begin{array}{c}\mathrm{r} \\
\text { hitung }\end{array}$ & $\begin{array}{c}\mathrm{r} \\
\text { tabel }\end{array}$ & $\begin{array}{c}\text { Sig } \\
\text { hitung }\end{array}$ & $\begin{array}{c}\text { Sig } \\
\text { tabel }\end{array}$ & $\begin{array}{c}\text { Ketera } \\
\text { ngan }\end{array}$ \\
\hline & $\begin{array}{l}\text { Kes } \\
\text { adar } \\
\text { an } \\
\end{array}$ & & & & & \\
\hline 1 & $\mathrm{X}_{21}$ & 0,653 & $\begin{array}{l}0.30 \\
6\end{array}$ & 0,000 & $\begin{array}{l}0,05 \\
0\end{array}$ & Valid \\
\hline 2 & $\mathrm{X}_{2.2}$ & 0,704 & $\begin{array}{l}0.30 \\
6 \\
\end{array}$ & 0,000 & $\begin{array}{l}0,05 \\
0 \\
\end{array}$ & Valid \\
\hline 3 & $\mathrm{X}_{2.3}$ & 0,764 & $\begin{array}{l}0.30 \\
6 \\
\end{array}$ & 0,000 & $\begin{array}{l}0,05 \\
0\end{array}$ & Valid \\
\hline 4 & $\mathrm{X}_{2.4}$ & 0,736 & $\begin{array}{l}0.30 \\
6 \\
\end{array}$ & 0,000 & $\begin{array}{l}0,05 \\
0 \\
\end{array}$ & Valid \\
\hline 5 & $\mathrm{X}_{2.5}$ & 0,725 & $\begin{array}{l}0.30 \\
6\end{array}$ & 0,000 & $\begin{array}{l}0,05 \\
0\end{array}$ & Valid \\
\hline 6 & $\mathrm{X}_{2.6}$ & 0,785 & $\begin{array}{l}0.30 \\
6 \\
\end{array}$ & 0,000 & $\begin{array}{l}0,05 \\
0 \\
\end{array}$ & Valid \\
\hline 7 & $\mathrm{X}_{2.7}$ & 0,853 & $\begin{array}{l}0,30 \\
6 \\
\end{array}$ & 0,000 & $\begin{array}{l}0,05 \\
0 \\
\end{array}$ & Valid \\
\hline 8 & $\mathrm{X}_{2.8}$ & 0,769 & $\begin{array}{l}0,30 \\
6 \\
\end{array}$ & 0,000 & $\begin{array}{l}0,05 \\
0 \\
\end{array}$ & Valid \\
\hline 9 & $\mathrm{X}_{2.9}$ & 0,726 & $\begin{array}{l}0,30 \\
6 \\
\end{array}$ & 0,000 & $\begin{array}{l}0,05 \\
0 \\
\end{array}$ & Valid \\
\hline $\begin{array}{l}1 \\
0 \\
\end{array}$ & $\begin{array}{l}\mathrm{X} 2 . \\
10 \\
\end{array}$ & 0,766 & $\begin{array}{l}0,30 \\
6 \\
\end{array}$ & 0,000 & $\begin{array}{l}0,05 \\
0 \\
\end{array}$ & Valid \\
\hline $\begin{array}{l}\mathrm{N} \\
\mathrm{o}\end{array}$ & $\begin{array}{l}\text { Vari } \\
\text { abel }\end{array}$ & $\begin{array}{l}\mathrm{r} \\
\text { hitung }\end{array}$ & $\begin{array}{l}\mathrm{r} \\
\text { tabel }\end{array}$ & $\begin{array}{l}\text { Sig } \\
\text { hitung }\end{array}$ & $\begin{array}{l}\text { Sig } \\
\text { tabel }\end{array}$ & $\begin{array}{l}\text { Ketera } \\
\text { ngan }\end{array}$ \\
\hline & $\begin{array}{l}\text { Sosi } \\
\text { alisa } \\
\text { si }\end{array}$ & & & & & \\
\hline 1 & $\mathrm{X}_{1.1}$ & 0,688 & $\begin{array}{l}0.30 \\
6 \\
\end{array}$ & 0,000 & $\begin{array}{l}0,05 \\
0\end{array}$ & Valid \\
\hline 2 & $\mathrm{X}_{1.2}$ & 0,825 & $\begin{array}{l}0.30 \\
6 \\
\end{array}$ & 0,000 & $\begin{array}{l}0,05 \\
0 \\
\end{array}$ & Valid \\
\hline 3 & $\mathrm{X}_{1.3}$ & 0,778 & 0.30 & 0,000 & 0,05 & Valid \\
\hline
\end{tabular}

\begin{tabular}{|c|c|c|c|c|c|c|}
\hline & & & 6 & & 0 & \\
\hline 4 & $\mathrm{X}_{1.4}$ & 0,817 & $\begin{array}{l}0.30 \\
6\end{array}$ & 0,000 & $\begin{array}{l}0,05 \\
0\end{array}$ & Valid \\
\hline 5 & $\mathrm{X}_{1.5}$ & 0,648 & $\begin{array}{l}0.30 \\
6 \\
\end{array}$ & 0,000 & $\begin{array}{l}0,05 \\
0 \\
\end{array}$ & Valid \\
\hline $\begin{array}{l}\mathrm{N} \\
0\end{array}$ & $\begin{array}{l}\text { Vari } \\
\text { abel }\end{array}$ & $\begin{array}{l}\mathrm{r} \\
\text { hitung }\end{array}$ & $\begin{array}{l}\mathrm{r} \\
\text { tabel }\end{array}$ & $\begin{array}{l}\text { Sig } \\
\text { hitung }\end{array}$ & $\begin{array}{l}\text { Sig } \\
\text { tabel }\end{array}$ & $\begin{array}{l}\text { Ketera } \\
\text { ngan }\end{array}$ \\
\hline & $\begin{array}{l}\text { Kep } \\
\text { atuh } \\
\text { an }\end{array}$ & & & & & \\
\hline 1 & $\mathbf{M}_{1.1}$ & 0,666 & $\begin{array}{l}0.30 \\
6\end{array}$ & 0,000 & $\begin{array}{l}0,05 \\
0\end{array}$ & Valid \\
\hline 2 & $\mathbf{M}_{1.2}$ & 0,746 & $\begin{array}{l}0.30 \\
6\end{array}$ & 0,000 & $\begin{array}{l}0,05 \\
0\end{array}$ & Valid \\
\hline 3 & $\mathrm{M}_{1.3}$ & 0,722 & $\begin{array}{l}0.30 \\
6\end{array}$ & 0,000 & $\begin{array}{l}0,05 \\
0\end{array}$ & Valid \\
\hline 4 & $\mathbf{M}_{1.4}$ & 0,582 & $\begin{array}{l}0.30 \\
6\end{array}$ & 0,000 & $\begin{array}{l}0,05 \\
0\end{array}$ & Valid \\
\hline 5 & $\mathbf{M}_{1.5}$ & 0,743 & $\begin{array}{l}0.30 \\
6\end{array}$ & 0,000 & $\begin{array}{l}0,05 \\
0\end{array}$ & Valid \\
\hline 6 & $\mathrm{M}_{1.6}$ & 0,725 & $\begin{array}{l}0.30 \\
6\end{array}$ & 0,000 & $\begin{array}{l}0,05 \\
0\end{array}$ & Valid \\
\hline 7 & $\mathbf{M}_{1.7}$ & 0,711 & $\begin{array}{l}0.30 \\
6\end{array}$ & 0,000 & $\begin{array}{l}0,05 \\
0\end{array}$ & Valid \\
\hline \multirow[t]{2}{*}{$\begin{array}{l}\mathrm{N} \\
\mathrm{O}\end{array}$} & $\begin{array}{l}\text { Vari } \\
\text { abel }\end{array}$ & $\begin{array}{l}\mathrm{r} \\
\text { hitung }\end{array}$ & $\begin{array}{l}\mathrm{r} \\
\text { tabel }\end{array}$ & $\begin{array}{l}\text { Sig } \\
\text { hitung }\end{array}$ & $\begin{array}{l}\text { Sig } \\
\text { tabel }\end{array}$ & $\begin{array}{l}\text { Ketera } \\
\text { ngan }\end{array}$ \\
\hline & $\begin{array}{l}\text { Pene } \\
\text { rima } \\
\text { an } \\
\text { Paja } \\
\mathrm{k}\end{array}$ & & & & & \\
\hline 1 & $Y_{1.1}$ & 0,571 & $\begin{array}{l}0.30 \\
6\end{array}$ & 0,000 & $\begin{array}{l}0,05 \\
0\end{array}$ & Valid \\
\hline 2 & $Y_{1.2}$ & 0,591 & $\begin{array}{l}0.30 \\
6\end{array}$ & 0,000 & $\begin{array}{l}0,05 \\
0\end{array}$ & Valid \\
\hline 3 & $\mathrm{Y}_{1.3}$ & 0,611 & $\begin{array}{l}0.30 \\
6\end{array}$ & 0,000 & $\begin{array}{l}0,05 \\
0\end{array}$ & Valid \\
\hline 4 & $Y_{1.4}$ & 0,690 & $\begin{array}{l}0.30 \\
6\end{array}$ & 0,000 & $\begin{array}{l}0,05 \\
0\end{array}$ & Valid \\
\hline 5 & $Y_{1.5}$ & 0,646 & $\begin{array}{l}0.30 \\
6 \\
\end{array}$ & 0,000 & $\begin{array}{l}0,05 \\
0 \\
\end{array}$ & Valid \\
\hline & & & & & & \\
\hline
\end{tabular}

Sumber : Data primer yang diolah, 2020

Menunjukkan bahwa semua indikator untuk mengukur variabel-variabel dalam penelitian ini mempunyai nilai $\mathrm{r}_{\text {hitung }}$ yang lebih besar dari $r_{\text {tabel, }}$ sehingga semua indikator valid.

b. Uji Realibilitas

\begin{tabular}{|l|l|l|l|}
\hline Variable & $\begin{array}{l}\text { Cron } \\
\text { Alpha }\end{array}$ & $\begin{array}{l}\text { Batas } \\
\text { Reabilitas }\end{array}$ & Keterangan \\
\hline Tarif & 0,777 & 0,600 & Reliabel \\
\hline Kesadaran & 0,776 & 0,600 & Reliabel \\
\hline Sosialisasi & 0,794 & 0,600 & Reliabel \\
\hline Kepatuhan & 0,773 & 0,600 & Reliabel \\
\hline $\begin{array}{l}\text { Peningkatan } \\
\text { Penerimaan }\end{array}$ & 0,744 & 0,600 & Reliabel \\
\hline
\end{tabular}

Sumber : Data sekunder yang diolah,2020 
Hasil pengujian menunjukan bahwa nilai koefisien Alpha dari variabel-variabel yang diteliti menghasilkan hasil yang beragam Tarif $(0,777)$, Kesadaran $(0,776)$, Sosialisasi $(0,794)$, Kepatuhan $(0,773)$ dan Peningkatan Penerimaan $(0,744)$ variabel menghasilkan nilai Cronbach Alpha lebih besar dari 0,600. Dengan demikian, dapat disimpulkan bahwa alat ukur yang digunakan dalam penelitian ini reliabel.

\section{Hasil Uji Asumsi Klasik}

a. Uji Normalitas

\begin{tabular}{|l|l|r|}
\hline \multicolumn{2}{|c|}{} & \multicolumn{2}{|c|}{ Standardized Residual } \\
\hline N & 130 \\
\hline $\begin{array}{l}\text { Normal } \\
\text { Parameters }\end{array}$ & Mean &, 0000000 \\
\cline { 2 - 3 } & $\begin{array}{l}\text { Std. } \\
\text { Deviation }\end{array}$ &, 98437404 \\
\hline $\begin{array}{l}\text { Most } \\
\text { Extreme } \\
\text { Differences }\end{array}$ & Absolute & Negative \\
\cline { 2 - 3 } & Positive &, 072 \\
\hline Test Statistic & Neg5 \\
\hline Asymp. Sig. (2-tailed) &,- 072 \\
\hline
\end{tabular}

Sumber : Data sekunder yang diolah,2020

Tabel diatas menunjukkan bahwa nilai sig. (2-tailed) sebesar 0,096 >0,05. Hal ini berarti nilai residual terstandarisasi dinyatakan menyebar secara normal (berada di dekat garis diagonal).

\section{b. Uji Multikolonieritas}

\begin{tabular}{|l|l|r|r|}
\hline \multicolumn{2}{|l|}{ Model } & \multicolumn{2}{|c|}{ Collinearity Statistics } \\
\cline { 3 - 4 } & Tolerance & \multicolumn{1}{c|}{ VIF } \\
\hline 1 & (Constant) & & \\
\cline { 2 - 4 } & Tarif &, 631 & 1,584 \\
\cline { 2 - 4 } & Kesadaran &, 395 & 2,533 \\
\cline { 2 - 4 } & Sosialisasi &, 438 & 2,282 \\
\cline { 2 - 4 } & Kepatuhan &, 495 & 2,019 \\
\hline
\end{tabular}

Sumber : Data sekunder yang diolah,2020

Berdasarkan tabel di atas masing-masing variable memiliki nilai tolerance $>0,100$. Sedangkan nilai VIF untuk variabel kualitas Tarif yaitu masing-masing variabel memiliki nilai VIF < 10, maka dapat disimpulkan pada model regresi yang terbentuk tidak terjadi gejala multikoliniearitas. Jika yang terjadi nilai VIF $>10$ dan nilai tolerance $<0,100$ maka terjadi multikolinieritas.

\section{c. Uji Heterokedastisitas}

\begin{tabular}{|c|c|c|c|c|c|c|}
\hline & \multirow{2}{*}{ Model } & \multicolumn{2}{|c|}{$\begin{array}{l}\text { Unstandardized } \\
\text { Coefficients }\end{array}$} & \multirow{2}{*}{ 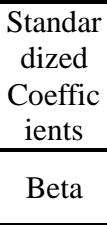 } & \multirow{2}{*}{$\mathrm{T}$} & \multirow{2}{*}{ Sig. } \\
\hline & & B & $\begin{array}{l}\text { Std. } \\
\text { Error }\end{array}$ & & & \\
\hline \multirow[t]{5}{*}{1} & (Constant & 8,164 & 1,504 & & 5,429 & ,000 \\
\hline & Tarif & ,137 & ,089 & ,141 & 1,534 &, 127 \\
\hline & $\begin{array}{l}\text { Kesadara } \\
\mathrm{n}\end{array}$ & ,008 & ,041 & ,021 & , 184 & ,855 \\
\hline & $\begin{array}{l}\text { Sosialisas } \\
\mathrm{i}\end{array}$ & ,182 & ,087 & ,232 & 2,102 & ,038 \\
\hline & $\begin{array}{l}\text { Kepatuha } \\
\mathrm{n}\end{array}$ & ,201 & ,071 & ,295 & 2,843 & ,005 \\
\hline
\end{tabular}

Sumber : Data sekunder yang diolah,2020

Dapat disimpulkan model regresi tidak terjadi gejala heteroskedastisitas. Sedangkan variabel X1 dan X2 nilai signifikannya $>0,05$ maka terjadi heteroskedastisitas.

\section{Uji Ketepatan Model}

Model 1: Variabel tarif, kesadaran dan sosialisasi terhadap peningkatan penerimaan pajak.

\begin{tabular}{|l|r|r|r|r|l|}
\hline Mo & $\mathrm{R}$ & $\mathrm{R}$ & Adjusted R & $\begin{array}{c}\text { Std. } \\
\text { Error } \\
\text { of the }\end{array}$ & $\begin{array}{l}\text { Durb } \\
\text { in-W } \\
\text { del }\end{array}$ \\
& & Square & Square & $\begin{array}{c}\text { Estimat } \\
\text { atson }\end{array}$ & \\
\hline 1 &, $537^{\mathrm{a}}$ &, 288 &, 271 & 2,199 & 1,961 \\
\hline
\end{tabular}

Sumber : Data sekunder yang diolah,2020

Berdasarkan tabel di atas dapat dilihat bahwa nilai $\mathrm{R}$ Square sebesar 0,288 yang artinya variabel tarif, kesadaran dan sosisalisasi memiliki kontribusi pengaruh terhadap peningkatan penerimaan pajak sebesar $28,8 \%$ dan sisanya $72,2 \%$ dijelaskan oleh variabel lain di luar variabel penelitian. 
Model 2: Variabel tarif, kesadaran dan sosialisasi terhadap kepatuhan wajib pajak.

\begin{tabular}{|l|l|r|r|r|l|}
\hline Mo & $\mathrm{R}$ & $\begin{array}{c}\text { R } \\
\text { Square }\end{array}$ & $\begin{array}{c}\text { Adjusted R } \\
\text { Square }\end{array}$ & $\begin{array}{c}\text { Error } \\
\text { of the } \\
\text { Estimat } \\
\text { Durb }\end{array}$ & $\begin{array}{l}\text { in-W } \\
\text { atson }\end{array}$ \\
\hline 1 &, $710^{\text {a }}$ &, 505 &, 493 & 2,701 & 2,268 \\
\hline
\end{tabular}

Sumber : Data sekunder yang diolah,2020

Berdasarkan tabel di atas dapat dilihat bahwa nilai $\mathrm{R}$ Square sebesar 0,505 yang artinya variabel tarif, keasadaran dan sosialisasi memiliki kontribusi pengaruh terhadap kepatuhan sebesar $50,5 \%$ dan sisanya yaitu $49,5 \%$ dijelaskan oleh variabel lain diluar variabel penelitian.

Model 3: Variabel kepatuhan terhadap peningkatan penerimaan pajak.

\begin{tabular}{|c|r|r|r|r|l|}
\hline Mo & $\mathrm{R}$ & $\mathrm{R}$ & Adjusted R & $\begin{array}{c}\text { Std. } \\
\text { Error } \\
\text { of the }\end{array}$ & $\begin{array}{l}\text { Durb } \\
\text { in-W } \\
\text { del }\end{array}$ \\
& & Square & Square & $\begin{array}{c}\text { Estimat } \\
\text { atson }\end{array}$ & \\
\hline 1 &, $509^{2}$ &, 259 &, 253 & 2.227 & 1.991 \\
\hline
\end{tabular}

Sumber : Data sekunder yang diolah,2020

Berdasarkan tabel di atas dapat dilihat bahwa nilai $R$ Square sebesar 0,259 yang artinya variabel kepatuhan memiliki kontribusi pengaruh terhadap $25,9 \%$ dan sisanya yaitu $75,1 \%$ dijelaskan oleh variabel lain diluar variabel penelitian.

Model 4: Variabel tarif dan kepatuhan terhadap peningkatan penerimaan pajak.

\begin{tabular}{|c|c|c|c|c|c|}
\hline $\begin{array}{l}\text { Mo } \\
\text { del }\end{array}$ & $\mathrm{R}$ & $\begin{array}{c}\mathrm{R} \\
\text { Square }\end{array}$ & $\begin{array}{c}\text { Adjusted R } \\
\text { Square }\end{array}$ & $\begin{array}{l}\text { Std. } \\
\text { Error } \\
\text { of the } \\
\text { Estimat }\end{array}$ & $\begin{array}{l}\text { Durb } \\
\text { in-W } \\
\text { atson }\end{array}$ \\
\hline 1 &, $542^{\mathrm{a}}$ & ,294 & ,283 & 2,182 & 1,885 \\
\hline
\end{tabular}

Sumber : Data sekunder yang diolah,2020

Berdasarkan tabel di atas dapat dilihat bahwa nilai $\mathrm{R}$ Square sebesar 0,294 yang artinya variabel tarif dan kepatuhan memiliki kontribusi pengaruh terhadap peningkatan penerimaan pajak sebesar $29,4 \%$ dan sisanya yaitu $21,6 \%$ dijelaskan oleh variabel lain diluar variabel penelitian.

Model 5: Variabel kesadaran dan kepatuhan terhadap peningkatan penerimaan pajak.

\begin{tabular}{|c|c|c|c|c|l|}
\hline Mo & $\mathrm{R}$ & $\mathrm{R}$ & Adjusted R & $\begin{array}{c}\text { Std. } \\
\text { Error } \\
\text { of the }\end{array}$ & $\begin{array}{l}\text { Durb } \\
\text { in-W } \\
\text { del }\end{array}$ \\
& & Square & Square & $\begin{array}{c}\text { Estimat } \\
\mathrm{e}\end{array}$ & atson \\
\hline 1 &, $527^{\mathrm{a}}$ &, 278 &, 267 & 2,206 & 2,033 \\
\hline
\end{tabular}

Sumber : Data sekunder yang diolah,2020

Berdasarkan tabel di atas dapat dilihat bahwa nilai $\mathrm{R}$ Square sebesar 0,278 yang artinya variabel kesadaran dan kepatuhan memiliki kontribusi pengaruh terhadap peningkatan penerimaan pajak sebesar $27,8 \%$ dan sisanya yaitu $73,2 \%$ dijelaskan oleh variabel lain diluar variabel penelitian.

Model 6: Variabel sosialisasi dan kepatuhan terhadap peningkatan penerimaan pajak.

\begin{tabular}{|l|r|r|r|r|l|}
\hline Mo & $\mathrm{R}$ & $\mathrm{R}$ & Adjusted R & $\begin{array}{c}\text { Std. } \\
\text { Error } \\
\text { of the }\end{array}$ & $\begin{array}{l}\text { Durb } \\
\text { in-W } \\
\text { del }\end{array}$ \\
& & Square & Square & \\
Estimat & atson \\
$\mathrm{e}$ & & \\
\hline 1 &, $565^{\mathrm{a}}$ &, 319 &, 308 & 2,143 & 1,942 \\
\hline
\end{tabular}

Sumber : Data sekunder yang diolah,2020

Berdasarkan tabel di atas dapat dilihat bahwa nilai $\mathrm{R}$ Square sebesar 0,319 yang artinya variabel tarif dan kepatuhan memiliki kontribusi pengaruh terhadap peningkatan penerimaan pajak sebesar 
$31,9 \%$ dan sisanya yaitu $69,1 \%$ dijelaskan oleh variabel lain diluar variabel penelitian.

\section{a. Hasil Uji Analisis Regresi Metode Kausal Step}

\section{Hasil Uji Model 1}

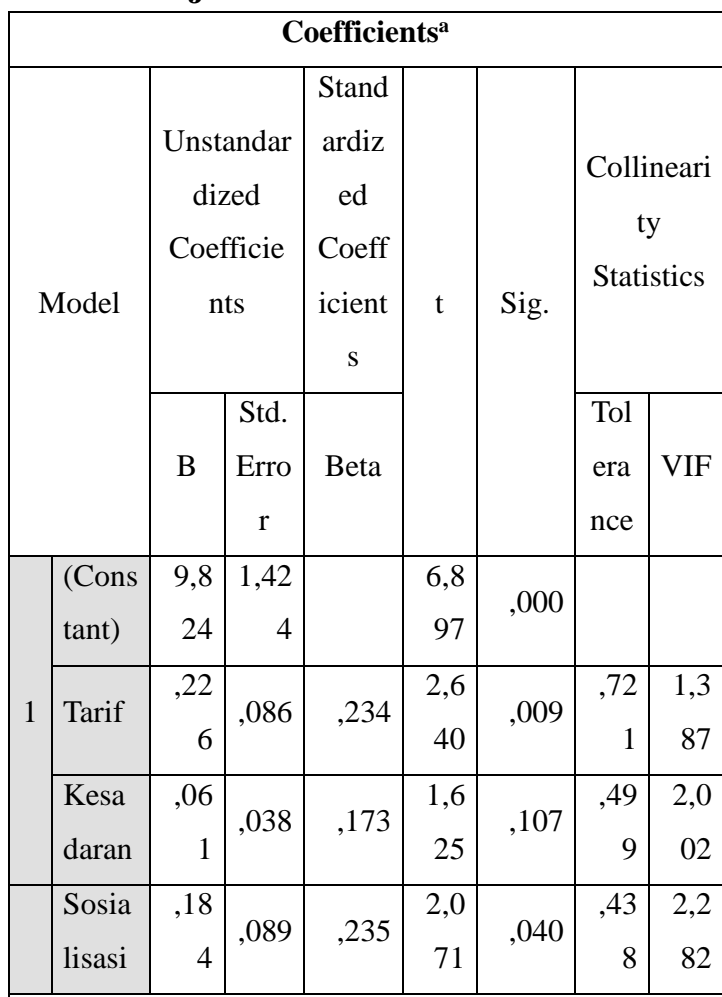

a. Dependent Variable: Peningkatan Penerimaan Pajak

\section{Pengaruh Tarif Terhadap Peningkatan Penerimaan Pajak.}

Variabel tarif mempunyai $t_{\text {hitung }}$ $(2,640)>t_{\text {tabel }}(1.978)$ dapat disimpulkan bahwa Tarif memiliki kontribusi pengaruh terhadap Peningkatan Penerimaan Pajak. Variabel Tarif mempunyai nilai signifikan $<0,05$ atau nilai 0,009 $<0,05$, maka Ho ditolak dan Ha diterima. Jadi dapat disimpulkan Tarif berpengaruh positif signifikan terhadap Peningkatan Penerimaan Pajak.

$\mathrm{H}_{1}$ : Tarif Berpengaruh Positif dan Signifikan Terhadap Peningkatan Penerimaan Pajak.

\section{Pengaruh Kesadaran terhadap Peningkatan Penerimaan Pajak.}

Variabel Kesadan mempunyai $t_{\text {hitung }}(1,625)>t_{\text {tabel }}(1,978)$ dapat disimpulkan bahwa Kesadaran memiliki kontribusi pengaruh terhadap Peningkatan Penerimaan Pajak. Variabel Kesadaran mempunyai nilai signifikan sebesar $>0,05$ atau nilai 0,107 >0,05, maka Ho diterima dan Ha ditolak. Jadi dapat disimpulkan Kesadaran tidak berpengaruh positif tidak signifikan terhadap Peningkatan Penerimaan Pajak.

$\mathrm{H}_{2}$ : Kesadaran Tidak Berpengaruh Positif dan Tidak Signifikan Terhadap Peningkatan Penerimaan Pajak.

\section{Pengaruh Sosialisasi terhadap} Peningkatan Penerimaan Pajak.

Variabel Sosialisasi mempunyai $t_{\text {hitung }}$ sebesar $(2,071)<t_{\text {tabel }}(1,978)$ dapat disimpulkan bahwa Sosialisasi memiliki kontribusi pengaruh terhadap Peningkatan Penerimaan Pajak. Variabel Sosiallisasi mempunyai nilai signifikan sebesar $<0,05$ atau nilai $0,040<0,05$, maka Ho ditolak dan Ha diterima. Jadi dapat disimpulkan Sosialisasi berpengaruh positif signifikan terhadap Peningkatan Penerimaan Pajak. $\mathrm{H}_{3}$ : Sosialisasi Berpengaruh Positif Dan Signifikan Terhadap Peningkatan Penerimaan Pajak.

\section{Hasil Uji Model 2}

\begin{tabular}{|c|c|c|c|c|c|c|c|c|}
\hline \multicolumn{9}{|c|}{ Coefficients $^{\mathrm{a}}$} \\
\hline \multirow{2}{*}{\multicolumn{2}{|c|}{ Model }} & \multicolumn{2}{|c|}{$\begin{array}{c}\text { Unstanda } \\
\text { rdized } \\
\text { Coefficie } \\
\text { nts }\end{array}$} & \multirow{2}{*}{$\begin{array}{c}\text { Stand } \\
\text { ardiz } \\
\text { ed } \\
\text { Coeff } \\
\text { icient } \\
\text { s } \\
\text { Beta }\end{array}$} & \multirow[t]{2}{*}{$\mathrm{t}$} & \multirow[t]{2}{*}{ Sig. } & \multicolumn{2}{|c|}{$\begin{array}{c}\text { Collineari } \\
\text { ty } \\
\text { Statistics }\end{array}$} \\
\hline & & B & $\begin{array}{l}\text { Std. } \\
\text { Err } \\
\text { or }\end{array}$ & & & & $\begin{array}{l}\text { Tol } \\
\text { era } \\
\text { nce }\end{array}$ & VIF \\
\hline \multirow{3}{*}{1} & $\begin{array}{l}\text { (Cons } \\
\operatorname{tant})\end{array}$ & $\begin{array}{r}8,2 \\
73\end{array}$ & $\begin{array}{r}1,7 \\
50\end{array}$ & & $\begin{array}{r}4,7 \\
28\end{array}$ & , 000 & & \\
\hline & Tarif & $\begin{array}{r}, 44 \\
6\end{array}$ & $\begin{array}{r}, 10 \\
5\end{array}$ & ,313 & $\begin{array}{r}4,2 \\
38\end{array}$ & , 000 & $\begin{array}{r}, 72 \\
1\end{array}$ & $\begin{array}{r}1,3 \\
87\end{array}$ \\
\hline & $\begin{array}{l}\text { Kesa } \\
\text { daran }\end{array}$ & $\begin{array}{r}, 26 \\
8\end{array}$ & $\begin{array}{r}, 04 \\
6\end{array}$ & ,513 & $\begin{array}{r}5,7 \\
78\end{array}$ & , 000 & $\begin{array}{r}49 \\
9\end{array}$ & $\begin{array}{r}2,0 \\
02\end{array}$ \\
\hline
\end{tabular}




\begin{tabular}{|l|l|r|r|r|r|r|r|r|}
\hline Sosia &, 01 &, 10 &, 010 &, 10 &, 916 &, 43 & 2,2 \\
& lisasi & 2 & 9 & & 6 & & 8 & 82 \\
\hline
\end{tabular}

a. Dependent Variable: Kepatuhan Wajib Pajak

\section{Pengaruh Tarif terhadap Kepatuhan Wajib Pajak}

Variabel Tarif mempunyai thitung sebesar $(4,238)>t_{\text {table }}(1,978)$ dapat disimpulkan bahwa Tarif memiliki kontribusi pengaruh terhadap Kepatuhan. Variabel Tarif mempunyai nilai signifikan sebesar 0,000 , nilai signifikan $<0,05$ atau nilai $0,000<0,05$, maka Ho ditolak dan Ha diterima. Jadi dapat disimpulkan Tarif berpengaruh positif dan signifikan terhadap Kepatuhan.

$\mathrm{H}_{4}$ : Tarif Berpengaruh Positif dan Signifikan Terhadap Kepatuhan Wajib Pajak

\section{Pengaruh Kesadaran terhadap Kepatuhan Wajib Pajak}

Variabel Kesadaran mempunyai $t_{\text {hitung }}$ sebesar $(5,778)>t_{\text {tabel }}(1,978)$ dapat disimpulkan bahwa Kesadaran memiliki kontribusi pengaruh terhadap Peningkatan Penerimaan Pajak. Variabel Kesadaran mempunyai nilai signifikan sebesar 0,000 atau nilai $0,000<0,05$, maka $\mathrm{Ho}$ ditolak dan $\mathrm{Ha}$ diterima. Jadi dapat disimpulkan Kesadaran berpengaruh positif signifikan terhadap Kepatuhan Wajib Pajak.

$\mathrm{H}_{5}$ : Kesadaran Berpengaruh Positif dan Signifikan Terhadap Kepatuhan Wajib Pajak.

\section{Pengaruh Sosialisasi terhadap Kepatuhan Wajib Pajak.}

Variabel Sosialisasi mempunyai thitung sebesar $(, 106)<t_{\text {tabel }}(1,978)$ dapat disimpulkan bahwa Sosialisasi tidak memiliki kontribusi pengaruh terhadap Kepatuhan Wajib Pajak. Variabel Sosialisasi mempunyai nilai signifikan sebesar > 0,05 atau nilai ,916>0,05, maka Ho diterima dan $\mathrm{Ha}$ ditolak. Jadi dapat disimpulkan Sosialisasi tidak berpengaruh positif tidak signifikan terhadap Kepatuhan Wajib Pajak.

$\mathrm{H}_{6}$ : Sosialisasi Tidak Berpengaruh Positif dan Tidak Signifikan Terhadap Kepatuhan Wajib Pajak.

\section{Hasil Uji Model 3}

\begin{tabular}{|c|c|c|c|c|c|}
\hline \multicolumn{6}{|c|}{ Coefficients $^{a}$} \\
\hline \multirow[b]{2}{*}{ Model } & \multicolumn{2}{|c|}{$\begin{array}{l}\text { Unstandardized } \\
\text { Coefficients }\end{array}$} & $\begin{array}{c}\text { Standardi } \\
\text { zed } \\
\text { Coefficie } \\
\text { nts }\end{array}$ & & \\
\hline & $\mathrm{B}$ & Std. Error & Beta & $\mathrm{T}$ & Sig. \\
\hline \begin{tabular}{l|l}
1 & $\begin{array}{l}\text { (Cons } \\
\text { tant })\end{array}$
\end{tabular} & 10.379 & 1.384 & & 7.501 &, 000 \\
\hline $\begin{array}{l}\text { Kepat } \\
\text { uhan }\end{array}$ & ,346 &, 052 & ,509 & 6,686 &, 000 \\
\hline
\end{tabular}

7. Pengaruh Kepatuhan terhadap Peningkatan Penerimaan Pajak

Variabel Kepatuhan mempunyai $t_{\text {hitung }}$ sebesar $t_{\text {hitung }}(6,686)>t_{\text {tabel }}(1,978)$ disimpulkan bahwa Kepatuhan memiliki kontribusi pengaruh terhadap peningkatan penerimaan pajak. Nilai thitung positif menunjukkan bahwa variabel kepatuhan mempunyai hubungan yang searah dengan peningkatan penerimaan pajak. Variabel kepatuhan mempunyai nilai signifikan < 0,05 atau nilai $0,000<0,05$, maka Ha diterima dan Ho ditolak. Jadi dapat disimpulkan bahwa kepatuhan berpengaruh positif dan signifikan terhadap peningkatan penerimaan pajak.

$\mathrm{H}_{7}$ : Kepatuhan Berpengaruh Positif dan Signifikan terhadap Peningkatan Penerimaan Pajak. 


\section{Hasil Uji Model 4}

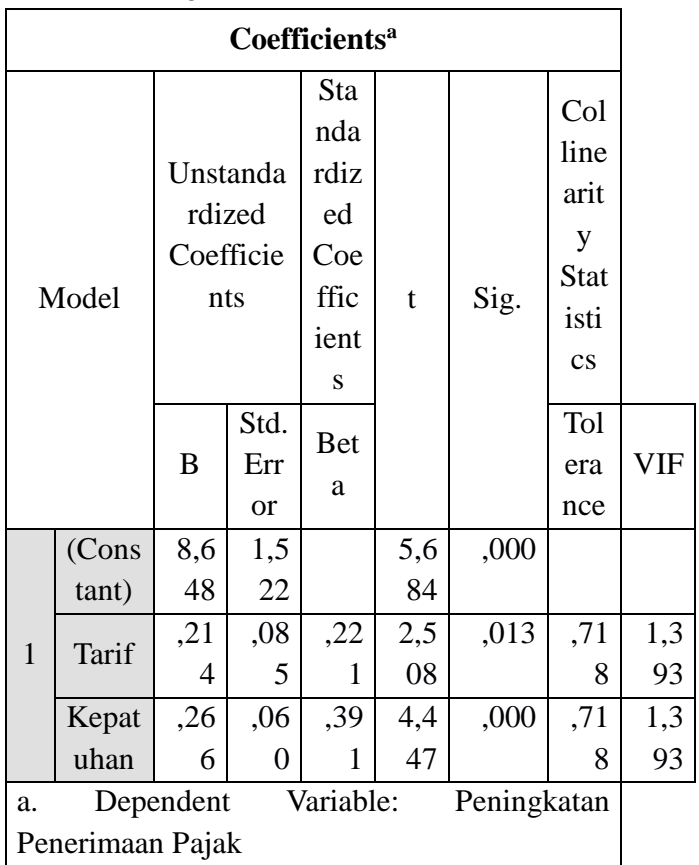

8. Pengaruh Tarif terhadap Peningkatan Penerimaan Pajak melalui Kepatuhan Wajib Pajak

a. Variabel tarif mempunyai $t$ hitung sebesar 2,508 dengan $\mathrm{t}$ tabel 1,978. Jadi $t$ hitung $>t$ tabel dapat disimpulkan bahwa tarif memiliki kontribusi pengaruh positif terhadap peningkatan penerimaan pajak. Variabel tarif mempunyai nilai signifikan sebesar atau nilai 0,013 $<$ 0,05, maka Ha diterima dan Ho ditolak. Jadi dapat disimpulkan tarif berpengaruh positif dan signifikan terhadap nilai perusahaan.

b. Variabel kepatuhan mempunyai $\mathrm{t}$ hitung sebesar 4,447 dengan $\mathrm{t}$ tabel 1,978. Jadi $\mathrm{t}$ hitung $>\mathrm{t}$ tabel dapat disimpulkan bahwa kepatuhan wajib pajak memiliki kontribusi pengaruh positif terhadap peningkatan penerimaan pajak. Variabel kepatuhan mempunyai nilai signifikan sebesar <
0,05 atau nilai $0,000<0,05$, maka $\mathrm{Ha}$ diterima dan Ho ditolak. Jadi dapat disimpulkan kepatuhan wajib pajak berpengaruh positif dan signifikan terhadap peningkatan penerimaan pajak.

$\mathrm{H}_{8}$ : Kepatuhan wajib pajak dapat memediasi hubungan antara Tarif dengan Peningkatan Penerimaan Pajak.

\section{Hasil Uji Model 5}

\begin{tabular}{|c|c|c|c|c|c|c|c|c|}
\hline \multicolumn{9}{|c|}{ Coefficients $^{\mathrm{a}}$} \\
\hline \multirow{2}{*}{\multicolumn{2}{|c|}{ Model }} & $\begin{array}{c}\text { Uns } \\
\text { tan } \\
\text { dar } \\
\text { dize } \\
\text { d } \\
\text { Coe }\end{array}$ & \multicolumn{2}{|c|}{$\begin{array}{c}\text { Standardi } \\
\text { zed } \\
\text { Coefficie } \\
\text { nts }\end{array}$} & \multirow[t]{2}{*}{$\mathrm{t}$} & \multirow[t]{2}{*}{ Sig. } & \multicolumn{2}{|c|}{$\begin{array}{l}\text { Collinear } \\
\text { ity } \\
\text { Statistics }\end{array}$} \\
\hline & & B & $\begin{array}{l}\text { Std. } \\
\text { Err } \\
\text { or }\end{array}$ & $\begin{array}{c}\text { Bet } \\
\mathrm{a}\end{array}$ & & & $\begin{array}{l}\text { Tol } \\
\text { era } \\
\text { nce }\end{array}$ & VIF \\
\hline \multirow{3}{*}{1} & $\begin{array}{c}\text { Cons } \\
\operatorname{tant})\end{array}$ & $\begin{array}{c}10, \\
095\end{array}$ & $\begin{array}{r}1,38 \\
0\end{array}$ & & $\begin{array}{r}7,3 \\
17\end{array}$ & ,000 & & \\
\hline & $\begin{array}{l}\text { Kesa } \\
\text { daran }\end{array}$ & $\begin{array}{r}, 06 \\
5\end{array}$ & ,035 & $\begin{array}{r}, 18 \\
2\end{array}$ & $\begin{array}{r}1,8 \\
38\end{array}$ & ,068 & $\begin{array}{r}57 \\
8\end{array}$ & $\begin{array}{r}1,7 \\
31\end{array}$ \\
\hline & $\begin{array}{c}\text { Kepat } \\
\text { uhan }\end{array}$ & $\begin{array}{r}, 26 \\
5\end{array}$ & ,067 & $\begin{array}{r}, 39 \\
0\end{array}$ & $\begin{array}{r}3,9 \\
34\end{array}$ & ,000 & $\begin{array}{r}, 57 \\
8\end{array}$ & $\begin{array}{r}1,7 \\
31\end{array}$ \\
\hline
\end{tabular}

9. Pengaruh Kesadaran terhadap Peningkatan Penerimaan Pajak melalui Kepatuhan.

a. Variabel kesadaran mempunyai $\mathrm{t}$ hitung sebesar 1,838 dengan $t$ tabel 1,978. Jadi $\mathrm{t}$ hitung $<\mathrm{t}$ tabel dapat disimpulkan bahwa kesadaran tidak memiliki kontribusi pengaruh positif terhadap peningkatan penerimaan pajak. Variabel kesadaran mempunyai nilai signifikan sebesar 0,068. Nilai signifikan $>0,05$ atau nilai $0,068>$ 0,05, maka Ha ditolak dan Ho diterima. Jadi dapat disimpulkan kesadaran tidak berpengaruh positif 
dan tidak signifikan terhadap peningkatan penerimaan pajak.

b. Variabel kepatuhan mempunyai $t$ hitung sebesar 3,934 dengan $t$ tabel 1,978. Jadi $\mathrm{t}$ hitung $>\mathrm{t}$ tabel dapat disimpulkan bahwa kepatuhan memiliki kontribusi pengaruh terhadap peningkatan penerimaan pajak. Variabel kepatuhan wajib pajak mempunyai nilai signifikan sebesar 0,000 . Nilai signifikan $<0,05$ atau nilai $0,658>0,05$, maka Ha diterima dan Ho ditolak. Jadi dapat disimpulkan kepatuhan wajib pajak berpengaruh positif dan signifikan terhadap peningkatan penerimaan pajak.

$\mathrm{H}_{9}$ : Kepatuhan tidak dapat memediasi hubungan antara Kesadaran dengan Peningkatan Penerimaan Pajak.

\section{Hasil Uji Model 6}

\begin{tabular}{|c|c|c|c|c|c|c|c|c|}
\hline \multicolumn{9}{|c|}{ Coefficients $^{\mathrm{a}}$} \\
\hline \multirow{2}{*}{\multicolumn{2}{|c|}{ Model }} & \multicolumn{2}{|c|}{$\begin{array}{l}\text { Unstanda } \\
\text { rdized } \\
\text { Coefficie } \\
\text { nts }\end{array}$} & $\begin{array}{l}\text { Sta } \\
\text { nda } \\
\text { rdiz } \\
\text { ed } \\
\text { Coe } \\
\text { ffic }\end{array}$ & \multirow[t]{2}{*}{$\mathrm{t}$} & \multirow[t]{2}{*}{ Sig. } & \multicolumn{2}{|c|}{$\begin{array}{c}\text { Collineari } \\
\text { ty } \\
\text { Statistics }\end{array}$} \\
\hline & & B & $\begin{array}{l}\text { Std. } \\
\text { Err } \\
\text { or }\end{array}$ & $\begin{array}{c}\text { Bet } \\
\mathrm{a}\end{array}$ & & & $\begin{array}{l}\text { Tol } \\
\text { era } \\
\text { nce }\end{array}$ & VIF \\
\hline \multirow{3}{*}{1} & $\begin{array}{l}\text { (Cons } \\
\text { tant) }\end{array}$ & $\begin{array}{r}9,0 \\
36\end{array}$ & $\begin{array}{r}1,3 \\
91\end{array}$ & & $\begin{array}{r}6,4 \\
96\end{array}$ & ,000 & & \\
\hline & $\begin{array}{l}\text { Sosia } \\
\text { lisasi }\end{array}$ & $\begin{array}{r}, 22 \\
7\end{array}$ & $\begin{array}{r}, 06 \\
8\end{array}$ & $\begin{array}{r}, 29 \\
0\end{array}$ & $\begin{array}{r}3,3 \\
48\end{array}$ & ,001 & $\begin{array}{r}, 71 \\
3\end{array}$ & $\begin{array}{r}1,4 \\
02\end{array}$ \\
\hline & $\begin{array}{c}\text { Kepe } \\
\text { rcaya } \\
\text { an }\end{array}$ & $\begin{array}{r}, 24 \\
0\end{array}$ & $\begin{array}{r}05 \\
9\end{array}$ & $\begin{array}{r}, 35 \\
3\end{array}$ & $\begin{array}{r}4,0 \\
74\end{array}$ & ,000 & $\begin{array}{r}, 71 \\
3\end{array}$ & $\begin{array}{r}1,4 \\
02\end{array}$ \\
\hline
\end{tabular}

10. Pengaruh Sosialisasi Pajak terhadap Peningkatan Penerimaan Pajak Melalui Kepatuhan Wajib Pajak. a. Variabel sosialisasi mempunyai $\mathrm{t}$ hitung sebesar 3,348 dengan $t$ tabel 1,978. Jadi $\mathrm{t}$ hitung $>\mathrm{t}$ tabel dapat disimpulkan bahwa sosialisasi memiliki kontribusi pengaruh positif terhadap peningkatan penerimaan pajak. Variabel sosialisasi mempunyai nilai signifikan sebesar 0,001. Nilai signifikan $<0,05$ atau nilai $0,001<$ 0,05, maka Ha diterima dan Ho ditolak. Jadi dapat disimpulkan sosialisasi berpengaruh positif dan signifikan terhadap peningkatan penerimaan pajak.

b. Variabel kepatuhan mempunyai $\mathrm{t}$ hitung sebesar 4,074 dengan $t$ tabel 1,978. Jadi $\mathrm{t}$ hitung $>\mathrm{t}$ tabel dapat disimpulkan bahwa kepatuhan memiliki kontribusi pengaruh positif terhadap peningkatan penerimaan pajak. Variabel kepatuhan wajib pajak mempunyai nilai signifikan sebesar 0,000 . Nilai signifikan $<0,05$ atau nilai $0,658<0,05$, maka Ha diterima dan Ho ditolak. Jadi dapat disimpulkan kebijakan kepatuhan berpengaruh positif dan signifikan terhadap peningkatan penerimaan pajak.

$\mathrm{H}_{10}$ : Kepatuhan dapat memediasi hubungan antara sosialisasi dengan peningkatan penerimaan pajak.

\section{Analisis Data dan Uji Hipotesis}

1. Ringkasan hasil uji regresi pengaruh secara langsung

\begin{tabular}{|c|c|c|c|c|}
\hline & Hubungan & $\begin{array}{c}\mathrm{t} \\
\text { Hitung }\end{array}$ & Sig. & Keterangan \\
\hline $\mathrm{X} 1$ & & $\begin{array}{c}2,64 \\
0\end{array}$ & 0,009 & $\begin{array}{l}\text { Berpengaruh } \\
\text { positif dan } \\
\text { Signifikan }\end{array}$ \\
\hline $\mathrm{X} 2$ & $\longrightarrow$ & $\begin{array}{c}1,62 \\
5\end{array}$ & 0,107 & $\begin{array}{l}\text { Tidak } \\
\text { berpengaruh } \\
\text { positif dan } \\
\text { Tidak } \\
\text { Signifikan }\end{array}$ \\
\hline $\mathrm{X} 3$ & & $\begin{array}{c}2,07 \\
1\end{array}$ & 0,040 & $\begin{array}{l}\text { Berpengaruh } \\
\text { positif dan }\end{array}$ \\
\hline
\end{tabular}




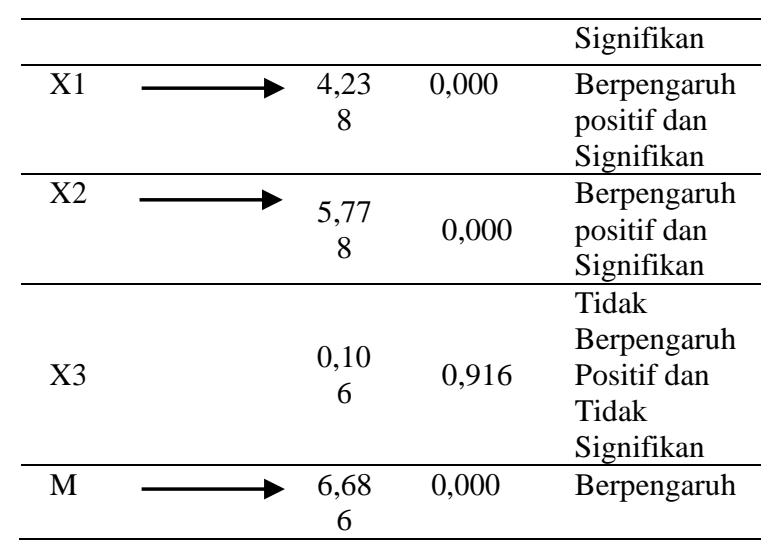

\section{Ringkasan hasil uji regresi} intervening

\begin{tabular}{|c|c|c|c|c|c|}
\hline \multirow[t]{2}{*}{ Hubungan } & \multicolumn{2}{|c|}{$\mathrm{T}$ hitung } & \multicolumn{2}{|c|}{ Sig } & \multirow[t]{2}{*}{ Keterangan } \\
\hline & $X$ & $\mathrm{M}$ & $\mathrm{X}$ & $\mathrm{M}$ & \\
\hline $\mathrm{X} 1 \longrightarrow \mathrm{M}$ & $\begin{array}{r}2,50 \\
8\end{array}$ & $\begin{array}{r}4,44 \\
7\end{array}$ & $\begin{array}{r}0,01 \\
3\end{array}$ & 0,000 & $\begin{array}{l}\text { Memed } \\
\text { iasi }\end{array}$ \\
\hline $\mathrm{X} 2 \longrightarrow \mathrm{M}$ & $\begin{array}{r}1,83 \\
8\end{array}$ & $\begin{array}{r}3,93 \\
4\end{array}$ & $\begin{array}{r}0,06 \\
8\end{array}$ & 0,000 & $\begin{array}{l}\text { Tidak } \\
\text { Memed } \\
\text { iasi }\end{array}$ \\
\hline $\mathrm{X} 3 \longrightarrow \mathrm{M}$ & $\begin{array}{r}3,34 \\
8\end{array}$ & $\begin{array}{r}4,07 \\
4\end{array}$ & $\begin{array}{r}0,00 \\
1\end{array}$ & 0,000 & $\begin{array}{l}\text { Memed } \\
\text { iasi }\end{array}$ \\
\hline
\end{tabular}

\section{PEMBAHASAN}

\section{Pengaruh Tarif Tarhadap Peningkatan Penerimaan Pajak}

Hasil penelitian ini menunjukan bahwa tarif pajak berpengaruh positif dan signifikan terhadap peningkatan penerimaan pajak.

Hasil penelitian ini sama hasil dengan penelitian yang dilakukan oleh Helmi Sularsih 2018 yang menyatakan bahwa tarif $0,5 \%$ penerapan PP 23 tahun 2018 berpengaruh positif terhadap peningkatan pajak UMKM di Kota Malang.

Tinggi rendahnya tarif secara garis lurus mampu mempengaruhi wajib pajak dalam membayarkan kewajiban pajak yang harus dipenuhi. Ketika tarif pajak cenderung rendah, wajib pajak tidak merasa terbebani dengan besaran pajak yang harus dibayarkan, hal tersebut dapat meningkatkan penerimaan pajak secara signifikan.

\section{Pengaruh Kesadaran Wajib Pajak Terhadap Peningkatan Penerimaan Pajak}

Hasil penelitian ini menunjukkan bahwa kesadaran Wajib Pajak tidak berpengaruh dan tidak signifikan terhadap peningkatan penerimaan pajak.

Hasil ini konsisten dengan hasil penelitian dari Marisa Herryanto dan Agus Arianto Toly (2013) yang membuktikan pengujiannya bahwa kesadaran wajib pajak berpengaruh negatif terhadap penerimaan. pajak penghasilan di KPP Pratama Surabaya Sawahan. Juga penelitian oleh Olivia Dewi dan Retna Ningtyas dalam penelitiannya menyatakan bahwa variabel kesadaran wajib pajak tidak berpengaruh terhadap keberhasilan penerimaan pajak Kota Tarakan.

Safri Numatu (2010) menyatakan bahwa kesadaran merupakan penilaian positif masyarakat wajib pajak terhadap pelaksanaan fungsi negara oleh pemerintah akan menggerakkan masyarakat untuk mematuhi kewajibannya untuk membayar. Dalam praktiknya, pelaku UMKM wajib pajak di Banjarnegara masih minim kesadaran perpajakan. Karena masih terdapat pemikiran bahwasannya pajak yang mereka bayarkan sering didapati penyalahgunaan oleh pihak yang tidak berwenang. Oleh sebab itu mereka belum memiliki rasa kesukarelaan untuk sepenuhnya meyakini bahwa pajak yang akan mereka bayarkan benar-benar dimanfaatkan kepada penggunaan yang seharusnya. Wajib Pajak Kecamatan Banjarnegara khususnya merasa masih terbebani atas 
tarif pajak yang berlaku dan merasa tidak mendapatkan manfaat secara langsung atas membayar pajak dalam kurun waktu tertentu walaupun secara tidak langsung manfaat tersebut telah mereka rasakan.

Apabila kesadaran masyarakat rendah, maka target pajak seringkali tidak terealisasi dengan baik dan benar. Untuk meningkatkan kesadaran Wajib Pajak dalam melakukan kewajiban perpajakannya, dibutuhkan persepsi yang positif terhadap pajak sehingga dalam membayar pajak, masyarakat tidak perlu bertanya-tanya manfaat dalam membayar pajak dan mempunyai kerelaan dalam membayar pajak.

\section{Pengaruh Sosialisasi Perpajakan} Terhadap Peningkatan Penerimaan Pajak

Hasil penelitian ini menunjukkan bahwa variabel sosialisasi berpengaruh positif dan signifikan terhadap peningkatan penerimaan pajak.

Hasil yang sama didapati pada penelitian Suyanto dan Kiftya Yahya (2016) berdasarkan analisis dan pengujian disimpulkan bahwa variabel sosialisasi perpajakan berpengaruh positif dan signifikan terhadap variabel penerimaan pajak penghasilan orang pribadi.

Menurut Saragih (2013), sosialisasi perpajakan adalah suatu upaya dari Dirjen Pajak untuk memberikan pengertian, informasi dan pembinaan kepada masyarakat pada umumnya dan Wajib Pajak pada khususnya mengenai segala sesuatu yang berhubungan dengan perpajakan dan perundang-undangan perpajakan. Teori atribusi menjelaskan tentang pemahaman akan reaksi seseorang terhadap peristiwa di sekitar mereka, dengan mengetahui alasan-alasan mereka atas kejadian yang dialami.

Sosialisasi perpajakan merupakan suatu upaya dari Direktorat Jenderal Pajak untuk memberikan pengertian, informasi dan pembinaan kepada masyarakat pada umumnya dan wajib pajak pada khususnya mengenai segala sesuatu yang berhubungan dengan perpajakan dan perundang-undangan Dengan diadakannya sosialisasi, maka Wajib Pajak mendapatkan informasi tentang pemberlakuan tarif baru, sanksi dan lain sebagainya serta menimbulkan reaksi untuk sadar akan kewajiban perpajakan yang harus dipenuhi.

4. Pengaruh Tarif Pajak Terhadap Kepatuhan Wajib Pajak

Hasil penelitian menunjukkan bahwa tarif pajak berpengaruh positif dan signifikan terhadap kepatuhan wajib pajak.

Sehasil dengan penelitian oleh Rika Nofiana, Afifudin (2020) hasil pengujiannya menunjukkan bahwa tarif pajak berpengaruh secara positif dan signifikan terhadap kepatuhan wajib pajak UMKM. Hasil positif lainnya dari jurnal akuntansi oleh Novia Tunggal Dewi (2019) yang menyebutkan bahwa tarif pajak berpengaruh positif terhadap kepatuhan wajib pajak.

Semakin rendah tarif pajak akan meningkatkan utility Wajib Pajak dan akan memberikan inisiatif bagi Wajib Pajak untuk melaporkan penghasilannya kepada administrasi pajak. Tarif dalam hal ini adalah tariff pajak atas penghasilan bruto tertentu sebesar $0,5 \%$ yang dikenakan terhadap Wajib Pajak yang omsetnya di bawah 4,8 Miliar Rupiah dalam satu tahun 
pajak. Sebelum bulan Juli Tahun 2018 pengenaan tarif kepada Wajib Pajak sebesar $1 \%$ untuk Wajib Pajak dan tarif Pajak Penghasilan pasal 17 untuk Wajib Pajak Orang Pribadi yang dikenakan berdasarkan penghasilan bruto dalam satu tahun pajak. Bila dilogikakan memang penetapan tarif pajak $0,5 \%$ lebih kecil, namun hal ini belum tentu menjadikan besarnya pajak yang terhutang menjadi lebih kecil juga, mungkin untuk beberapa UMKM yang omsetnya lebih tinggi menguntungkan, tapi jika diperhatikan tidak semua UMKM memiliki omset yang tinggi memperoleh hasil yang tinggi juga.

Wajib Pajak akan cenderung mempertimbangkan tarif untuk menimbulkan sifat patuh terhadap pembayaran pajak. Tarif pajak yang rendah akan mendorong Wajib Pajak untuk taat perpajakan karena mereka merasa tidak merasa terlalu terbebani dengan besaran tarif yang rendah.

\section{Pengaruh Kesadaran Wajib Pajak} Terhadap Kepatuhan Wajib Pajak

Hasil penelitian ini menunjukkan bahwa kesadaran wajib pajak berpengaruh posistif dan signifikan terhadap kepatuhan wajib pajak.

Konsisten dengan penelitian yang dilakukan oleh Eti, Sufia (2019) yang menunjukkan bahwa penerapan UU no.23 tahun 2018 mempengaruhi kesadaran wajib pajak dan kepatuhan wajib pajak. Juga oleh Anisa Fitriana (2019) dalam penelitiannya membuktikan bahwa perubahan tarif pajak memberikan kesadaran dan pengaruh terhadap kepatuhan wajib pajak.

Menurut Sari (2014) kesadaran Wajib Pajak akan meningkat jika masyarakat memiliki persepsi positif tentang pajak. Kesadaran yang dimiliki oleh manusia meliputi kesadaran dalam diri, akan diri sesama, masa silam, dan kemungkinan masa depannya (Widayati dan Nurlis, 2010). Pada teori atribusi menjelaskan bahwa kesadaran wajib pajak merupakan penyebab internal yang dapat mempengaruhi persepsi wajib pajak dalam membuat keputusan mengenai perilaku kepatuhan wajib pajak dalam melaksanakan kewajiban perpajakan.

Wajib pajak yang memiliki kesadaran lebih mengenai pentingnya pembayaran pajak, melaksanakan penghitungan, pembayaran juga pelaporan pajak dengan sukarela dan menyadari bhawa hal tersebut akan berdampak pada keberlangsungan kelancaran usaha meraka, cenderung memiliki tingkat kepatuhan yang lebih dalam membayar pajak.

\section{Pengaruh Sosialisasi Perpajakan} Terhadap Kepatuhan Wajib Pajak

Hasil penelitian ini menunjukkan bahwa sosialisasi perpajakan tidak berpengaruh dan tidak signifikan terhadap kepatuhan wajib pajak.

Searah dengan hasil penelitian dari Meiska Lianty dan Dini Wahjoe Hapsari (2017) yang menyatakan bahwa sosialisasi perpajakan tidak berpengaruh signifikan terhadap kepatuhan Wajib Pajak OP (Non Karyawan) di KPP Pratama Bandung Bojonagara. Juga penelitian yang diakukan oleh Yuliasari, et al (2015) yang menyatakan bahwa sosialisasi perpajakan tidak berpengaruh secara signifikan terhadap kepatuhan Wajib Pajak Orang Pribadi.

Menurut Rohmawati, Prasetyono, Rimawati (2013), sosialisasi 
perpajakan adalah upaya yang dilakukan oleh Dirjen Pajak untuk memberikan sebuah pengetahuan kepada masyarakat dan khususnya Wajib Pajak agar mengetahui tentang segala hal mengenai perpajakan baik peraturan maupun tata cara perpajakan melalui metode-metode yang tepat.

Sosialisasi perpajakan yang kurang tergambar melalui jawaban-jawaban responden yang lebih besar menunjukkan jawaban kurang setuju dengan pernyataan pernyataan pada kuesioner. Berdasarkan hasil kuesioner dapat dilihat bahwa sebagian besar responden belum mengetahui adanya sosialisasi perpajakan baik secara langsung maupun tidak langsung dan mereka belum mengikuti sosialisasi serta memperoleh informasi perpajakan melalui sosialisasi tersebut yang dapat membuat responden atau Wajib Pajak menjadi paham mengenai aspek teknis perpajakan dan menjadi peduli serta sadar akan pentingnya pajak bagi negara dan masyarakat. Dalam lingkup pelaku UMKM tidak sedikit yang belum mengikuti sosisalisasi perpajakan dan memperoleh informasi PP 28 tahun 2018. Sebagaian dari mereka mengetahui pertauran terbaru tersebut dari pelaku UMKM yang sudah menerapkan tarif pajak tersebut lebih dahulu.

\section{Pengaruh Kepatuhan Wajib Pajak Terhadap Peneriman Pajak}

Hasil penelitian ini menunjukkan bahwa kepatuhan wajib pajak berpengaruh positif dan signifikan terhadap peningkatan penerimaan pajak. Sesuai dengan hasil penelitian terdahulu oleh Olivia Jessica Yusuf dkk (2017) yang menyatakan bahwa tingkat kepatuhan wajib pajak orang pribadi berpengaruh positif terhadap penerimaan pajak.

Hasil penelitian yang lain disimpulkan oleh Maria M Ratnasari dan Ni Nyoman Afriyanti berdasarkan hasil analisis diketahui bahwa kepatuhan wajib pajak dan pemeriksaan pajak berpengaruh signifikan terhadap penerimaan pajak penghasilan pasal 25/29 wajib pajak badan pada Kantor Pelayanan Pajak Pratama Denpasar Timur. Kepatuhan wajib pajak dan pemeriksaan pajak secara parsial berpengaruh signifikan terhadap penerimaan pajak penghasilan pasal 25/29 wajib pajak badan pada Kantor Pelayanan Pajak Pratama Denpasar Timur periode 2004-- 2008.

Herbert Kelman (dalam Tondok, Ardiansyah \& Ayuni, 2012) mendefinisikan kepatuhan sebagai perilaku mengikuti permintaan otoritas meskipun individu secara personal individu tidak setuju dengan permintaan tersebut. Kepatuhan mengandung arti kemauan mematuhi sesuatu dengan takluk, tunduk (Neufeldt, Victoria; David B. Guralnik, dalam Widyarti, 2004).

Ketika seseorang patuh maka dengan penuh kesadaran Wajib Pajak akan membayarkan kwajibannya sesuai dengan yang berlaku. Jika tingkat kepatuhan seseorang tinggi maka penerimaan pajak cenderung tinggi pula. Dalam hasil penelitian ini kepatuhan wajib pajak di kecamatan Banjarnegara sendiri tergolong cukup baik. Karena mereka yang mempunyai NPWP aktif merasa mempunyai tanggungan untuk membayar pajak agar terhindar dari surat teguran dan denda telat bayar pajak. Kapatuhan 
Wajib Pajak sendiri tidak luput dari lingkungan lingku yang mendukung akan pentingnya mematuhi peraturan yang berlaku khususnya membayar dan melaporkan pajak sesuai ketentuan yang berlaku.

\section{Pengaruh Tarif Terhadap Peningkatan Penerimaan Pajak Melalui Kepatuhan Wajib Pajak}

Hasil penelitian ini menunjukkan bahwa kepatuhan dapat memediasi antara tarif pajak dengan peningkatan penerimaan pajak. Sama metode dengan penelitian yang dilakukan oleh Riris Rotua dan Yeni (2017) yang menghasilkan bahwa pengaruh e-commerce terhadap jumal pajak yang disetor dengan kepatuhan wajib pajak sebagai variabel intervening berpengaruh positif signifikan.

Teori yang menghubungkan pengaruh tarif terhadap peningkatan penerimaan pajak melalui kepatuhan adalah menurut Adam Smith (1776) dalam bukunya Wealth of Nations, salah satu ajaran yang terkenal mengenai perpajakan adalah The Four Maxims. Menurut Smith ada empat asas pemungutan pajak yaitu, asas Equality (keadilan), asas Certainly (kepastian hukum), asas Convenience of Payment (Pemungutan Pajak Tepat Waktu), dan asas Eficiency (Efisiensi). Asas Equality (keadilan) memberi penekanan bahwa pemungutan pajak dilakukan oleh negara harus sesuai dengan kemampuan dan penghasilan wajib pajak. Negara tidak boleh bertindak diskriminatif terhadap wajib pajak.

Saat wajib pajak berlaku patuh dan menaati segala aturan perpajakan yang telah ditetapkan hal ini akan mendorong proses pelaksanaan perpajakan berjalan lancar. . Hal ini sesuai dengan pendapat yang dinyatakan oleh Santoso (2008) bahwa pada tingkat penghasilan dan penghasilan yang dilaporkan tertentu, tarif pajak yang tinggi akan berpengaruh negatif terhadap utility Wajib Pajak. Semakin rendah tarif pajak akan meningkatkan utility Wajib Pajak dan akan memberikan inisiatif bagi Wajib Pajak untuk melaporkan penghasilannya kepada administrasi pajak.

Ditunjang dari Perubahan tarif pajak $1 \%$ menjadi $0.5 \%$ akan menimbulkan reaksi taat membayar pajak dan tidak lagi terbebani oleh tarif yang besar. Wajib Pajak Kecamatan Banjarnegara khususnya mengaku setuju dengan tarif baru ini. Karena sama konsep dengan PP 46 tahun 2013 yang menerapkan $1 \%$ dari bruto dalam pembayarannya maka PP 23 tahun 2018 ini lebih meringankan dalam membayar pajak karena hanya bertarif $0,5 \%$ dari peredaran bruto tertentu. Dari dua hal tersebut

\section{Pengaruh Kesadaran Wajib Pajak Terhadap Peningkatan Penerimaan Pajak Melalui Kepatuhan Wajib Pajak}

Hasil penelitian ini menunjukkan bahwa kepatuhan tidak dapat memediasi antara kesadaran wajib pajak dengan peningkatan penerimaan pajak.

Sehasil dengan penelitian yang dilakukan oleh Oktaviani, Hardiningsih dan Srimindari (2017) yang menyatakan bahwa kepatuhan wajib pajak tidak berhasil memediasi pengaruh kesadaran wajib pajak terhadap penerimaan pajak penghasilan. 
Kesadaran wajib pajak menurut Nasution (2013) menyatakan bahwa kesadaran wajib pajak merupakan sikap wajib pajak yang memahami dan mau melaksanakan kewajibannya untuk membayar pajak dan telah melaporkan semua penghasilannya tanpa ada yang disembunyikan sesuai dengan ketentuan yang berlaku. Pengertian Penerimaan Pajak menurut Suryadi (2009) merupakan sumber pembiayaan negara yang dominan baik untuk belanja rutin maupun pembangunan.

Kepatuhan wajib pajak bisa tercermin dalam nilai selisih antara rencana penerimaan pajak tersebut. Apabila semua wajib pajak UMKM menaati dan patuh terhadap peraturan perpajakan yang berlaku, maka selisih antara rencana penerimaan pajak dengan realisasi penerimaan menjadi nol atau lebih. Secara sederhana, meningkatnya kesadaran dan kepatuhan wajib pajak akan tercermin pada menyempitnya selisih antara rencana penerimaan pajak dengan realisasi penerimaan pajak. Dalam penerapan self assessment system, kesadaran dan kepatuhan wajib pajak sangat menentukan jumlah pajak yang akan diterima oleh negara yang nantinya akan mempengaruhi penerimaan anggaran yang diajukan oleh daerah untuk kemajuan negara.

Dalam penelitian ini, variabel kepatuhan wajib pajak tidak signifikan sebagai variabel mediasi dari kesadaran wajib pajak terhadap peningkatan penerimaan pajak. Olehkarena itu tidak ada pengaruh tidak langsung antara kesadaran wajib pajak terhadap peningkatan penerimaan pajak melalui kepatuhan wajib pajak.
10. Pengaruh Sosialisasi Terhadap Peningkatan Penerimaan Pajak Melalui Kepatuhan

Hasil penelitian ini menunjukkan bahwa kepatuhan dapat memediasi antara sosialisasi dengan ipeningkatan penerimaan pajak.

Sejalan dengan penelitian oleh Priyance Nababan dan Susi Dwimulyani (2019) yang berpendapat bahwa kepatuhan wajib pajak memediasi antara sosialisasi pajak terhadap kinerja KPP memalui kepatuhan wajib pajak sebagai Yenny Kopong dan Indah Widyaningrum (2016) yang menyimpulkan bahwa kepatuhan Wajib Pajak sebagai variabel moderating sosialisasi perpajakan berpengaruh signifikan terhadap Penerimaan Pajak.

Menurut Saragih (2013), sosialisasi perpajakan adalah suatu upaya dari Dirjen Pajak untuk memberikan pengertian, informasi dan pembinaan kepada masyarakat pada umumnya dan Wajib Pajak pada khususnya mengenai segala sesuatu yang berhubungan dengan perpajakan dan perundang-undangan perpajakan. Salah satu dasar penerimaan pajak sesuai target adalah kepatuhan wajib pajak. Kepatuhan Wajib Pajak adalah kondisi dimana Wajib Pajak memenuhi kewajiban perpajakan dan melaksanakan hak perpajakan, Rohmawati (2012).

Variabel intervening yang digunakan dalam penelitian ini adalah kepatuhan karena sosialisasi perpajakan dan kepatuhan adalah dua hal yang berbeda yang secara tidak langsung mempunyai hubungan (Anwar, 2015). Kepatuhan bisa menjadi intervening bagi sosialisasi 
perpajakan dalam mempengaruhi peningkatan penerimaan pajak. Semakin tinggi tingkat sosialisasi perpajakan maka semakin tinggi tingkat kepatuhan perpajakan, dan semakin tinggi tingkat kepatuhan perpajakan maka akan semakin tinggi peningkatan penerimaan pajak.

Sosialisasi perpajakan dilakukan untuk memberikan informasi yang baik dan benar sehingga wajib pajak akan memiliki pengetahuan tentang arti pentingnya membayar pajak dan pada akhirnya akan meningkatkan kepatuhan wajib pajak orang pribadi. Jika sosialisasi perpajakan disampaikan dengan jelas, benar, dan nyaman oleh petugas pajak maka wajib pajak akan memiliki pengetahuan tentang arti pentingnya membayar pajak yang secara otomatis akan meningkatkan kepatuhan wajib pajak.

\section{SIMPULAN DAN SARAN}

\section{Simpulan}

Berdasarkan hasil analisis data dan pembahasan yang telah diuraikan, maka dapat diambil kesimpulan sebagai berikut:

1. Tarif Pajak berpengaruh positif dan signifikan sebesar 2,640 t hitung > t tabel dan nilai signifikan $<0,05$ terhadap peningkatan penerimaan pajak, artinya tarif mempunyai pengaruh terhadap peningkatan penerimaan pajak.

2. Kesadaran Wajib Pajak tidak berpengaruh positif dan tidak signifikan sebesar 1,625 t hitung $<\mathrm{t}$ tabel dan nilai signifikan $>0,05$ terhadap peningkatan penerimaan pajak, artinya kesadraan Wajib Pajak tidan memiliki pengaruh terhadap peningkatan penerimaan pajak.
3. Sosialisasi perpajakan berpengaruh positif dan signifikan sebesar 2,071 t hitung > t tabel dan nilai signifikan < 0,05 terhadap peningkatan penerimaan pajak, artinya sosisalisasi perpajakan memiliki pengaruh terhadap peningkatan penerimaan pajak.

4. Tarif pajak berpengaruh positif dan signifikan sebesar 4,238 $\mathrm{t}$ hitung $>\mathrm{t}$ tabel dan nilai signifikan $<0,05$ terhadap kepatuhan wajib pajak, artinya tari pajak memiliki pengaruh terhadap kepatuhan wajib pajak.

5. Kesadaran wajib pajak berpengaruh positif dan signifikan sebesar 5,778 t hitung > t tabel dan niai signifikan < 0,05 terhadap kepatuhan wajib pajak, artinya kesadaran wajib pajak memiliki pengaruh terhadap kepatuhan wajib pajak.

6. Sosialisasi perpajakan tidak berpengaruh positif dan tidak signifikan sebesar $0,106 \mathrm{t}$ hitung $<\mathrm{t}$ tabel dan nilai signifikan $>0,05$ terhadap kepatuhan wajib pajak, artinya sosialisasi perpajakan tidak memiliki pengaruh terhadap kepatuhan wajib pajak.

7. Kepatuhan wajib pajak berpengaruh positif dan signifikan sebesar $6,686 \mathrm{t}$ hitung > t tabel dan nilai signifikan < 0,05 terhadap peningkatan penerimaan pajak, artinya kepatuhan wajib pajak memiliki pengaruh terhadap peningkatan penerimaan pajak.

8. Kepatuhan wajib pajak dapat memediasi hubungan antara tarif pajak dengan peningkatan penerimaan pajak.

9. Kepatuhan wajib pajak tidak dapat memediasi hubungan antara kesadaran wajib pajak dengan peningkatan penerimaan pajak.

10. Kepatuhan wajib pajak dapat memediasi hubungan antara sosisalisasi 
perpajakan terhadap peningkatan penerimaan pajak.

\section{Saran}

Berdasarkan hasil kesimpulan dalam penelitian ini, maka ada beberapa saran yang dapat diberikan oleh peneliti yaitu:

1. Saran untuk fiskus, agar lebih memperhatikan empat dimensi penting dalam meningkatkan kesadaran wajib pajak yaitu menciptakan persepsi positif Wajib Pajak terhadap kewajiban perpajakannya dengan membangun pemahaman pemanfaatan pajak yang tidak lain untuk fasilitas rakyat, mempelajari karakteristik Wajib Pajak melalui sosialisasi antar daerah/kecamatan masing-masing pelaku UMKM, meningkatkan pengetahuan perpajakan Wajib Pajak. Lebih sering dan terarah dalam melakukan sosialisasi khususnya kepada wajib pajak UMKM mengenai PP 23/2018 agar dapat meningkatkan pemahaman wajib pajak mengenai peraturan tersebut, sehingga informasi yang diperoleh dari sosialisasi tersebut dapat diimplementasikan dengan baik oleh wajib pajak UMKM.

2. Bagi wajib pajak UMKM, seharusnya lebih sadar pajak dan dapat memahami untuk memenuhi kewajiban perpajakannya, menggali informasi terhadap pihak - pihak terkait antara pelaku UMKM dan hal - hal yang harus dipenuhi sebagai pelaku UMKM, serta paham bahwa dampak membayar pajak tidak dapat dirasakan secara langsung.

3. Bagi peneliti selanjutnya, dapat mengganti variabel dengan variabel bebas yang lain dan memperluas area penelitian. Teknik pengambilan sampel jika menggunakan data primer sebaiknya tidak hanya dengan menggunakan kuesioner saja, melainkan wawancara dengan pendekatan kepada pelaku UMKM agar hasil lebih kompleks. Dan ditujukan kepada responden yang cenderung belum memiliki NPWP dan kuesioner mengacu pada faktor apa saja yang membuat Wajib Pajak merasa keberatan membayar pajak.

\section{Daftar Pustaka}

Abimanyu, A. (2013). Reformasi Perpajakan Perlu Dukungan Masyarakat. Badan Analisa Fiskal Departemen Keuangan. URL: http://www. fiskal. depkeu. go. id/beta/kolom1. Asp.

Andrieani, Agnes. (2016). Pengaruh Kesadaran Wajib Pajak, Pelayanan Perpajakan dan Kepatuhan Wajib Pajak Terhadap Penerimaan Pajak pada Kantor Pelayanan Pajak Pratama Medan Timur. Skripsi. Medan: Fakultas Ekonomi dan Biasnis Islam Negeri Sumatera Utara.

Ghozali, Imam. 2011. Aplikasi Analisis Multivariate Dengan Program SPSS. Semarang: Universitas Diponegoro

Herriyanto, Marisa dan Arianto, Agus. (2013). Pengaruh Kesadaran Wajib Pajak, kegiatan Sosialisasi Perpajakan, dan Pemeriksaan Pajak terhadap Penerimaaan Pajak Penghasilan di KPP Pratama Surabaya Sawahan. Jurnal Tax Accounting Riview, Vol.1, No.1, 2013 Akuntansi Pajak. Surabaya: Universitas Kristen Petra.

Hestanto, 2011. Teori Pendapatan Ekonomi, Hestanto Personal Website. 
Hestanto, 2012. Teori Atribusi. (Online) diakses dari hestanto.web.id.

Hestanto. Kumpulan Pengertian Pendapatan. (Online) diakses dari hestanto.web.id. 9 Desember 2019.

Kepatuhan, Pengaruh Tingkat Kepatuhan. (Online) diakses dari www.neliti.com

Kurnia Lola, Kardoyo, Rusdarti. (2018). The Socialization os Tax as a Moderation Variable Towards the Taxpayer Compliance of Industrial Performer in Kudus Regency. JEE 7 (1) 2018. Semarang: Universitas Negeri Semarang, Indonesia.

Kusuma, Dewi dan Wati, Erna. (2018). Pengaruh Ssialisasi Perpajakan Terhadap Kepatuhan Wajib Pajak dengan Pengetahuan Perpajakan Sebagai Variabel Intervening Studi pada Wajib Pajak Orang Pribadi di KPP Pratama Kebumen. Jurnal Nominal Volume VII Nomor 1 Tahun 2018 Fakultas Ekonomi. Yogyakarta: Universitas Sarjanawiyata Tamansiswa.

Mardiasmo, (2011) Perpajakan Edisi Revisi 2011. Penerbit Andi, Yogyakarta.

Pengertian Pajak Menurut Para Ahli, Tujuan dan Manfaat Pajak. Diakses dari lifepal.co.id.

Pengertian Pendapatan Menurut Para Ahli. (Online) diakses dari gurupendidikan.co.id.

Pengertian Tarif Pajak dan Jenis-jenis Tarif Pajak. (Online) diakses dari ilmumanajemendanakuntansi.blo gspot.com.
PP Nomor 23 Tahun 2018. (Online) diakses dari klikpajak.id.

Rizki Pasca, Kumadji, dan Husaini. (2015). Pengaruh Sosialisasi Perpajakan, Tarif Pajak, dan Pemahaman Perpajakan Terhadap Kepatuhan Wajib Pajak (Studi pada UMKM yang Terdaftar sebagai Wajib Pajak di Kantor Pelayanan Pajak Pratama Batu). Jurnal Perpajakan JejakVol.6 No.2 2015. Jurusan Administrasi Bisnis Fakultas Ilmu Administrasi. Malang: Universitas Brawijaya.

Saragih, S. F. (2013). Analisis Pengaruh Sosialisasi Perpajakan, Kualitas Pelayanan Fiskus dan Sanksi Perpajakan Terhadap kepatuhan Wajib Pajak Orang Pribadi di Kantor Pelayanan Pajak Pratama Medan Timur. Skripsi. Fakultas Ekonomi Universitas Sumatera Utara: Medan.

Setiawati, Afrina. (2017). Pengaruh Kepatuhan Wajib Pajak, Pemeriksaan Pajak, dan Kegiatan Sosialisasi Perpajakan Terhadap Peningkatan Penerimaan Pajak Penghasilan Studi Empiris pada Kantor Pelayanan Pajak Pratama Pekanbaru Tampan. Jurnal JOM Fekon, Vol.4 No. 2 Oktober 2017 Fakultas Ekonomi dan Bisnis. Riau: Universitas Pekanbaru Indonesia.

Sidawati, Insan. (2016). Pengaruh Kesadaran Wajib Pajak, Kegitan Sosialisasi Perpajakan, dan Pemeriksaan Pajak Terhadap Penerimaan Pajak Penghasilan di KPP Pratama Bndung Cibeunying. Jurnal 2016. 
Bandung: Universitas

Pendidikan Indonesia.

Sugiyono, (2010). Buku Metode Penelitian Pendidikan(Online)

Sugiyono.

https://widisudharta./metode-pen

elitian-skripsi.html diakses 29

Desember 2020.

Sugiyono (2015). Metode Penelitian

Kombinasi (Mix Methods).

Bandung: Alfabeta.

Sugiyono. (2017). Metode Penelitian

Kuantitatif, Kualitatif, dan R\&D.

Bandung: Alfabeta

Suliyanto, (2011), Ekonometrika Terapan-

Teori dan Aplikasi dengan SPSS,

Penerbit

CV.ANDI

OFFSET, Yogyakarta.

Suyanto dan Yahya, Kiftia. (2016).

Pengaruh Sosialisasi Perpajakan

Dan Ekstensifikasi Pajak

Terhadap Penerimaan Pajak

Penghasilan Orang Pribadi Studi

Kasus di KPP Pratama Wonosari

Yogyakarta. Jurnal JEAM Vol

XV April 2016. Yogyakarta:

Universitas SarjanaWiyata

Tamansiswa.

Undang - Undang Perpajakan.

Undang-Undang RI Nomor 17 Tahun

2003 tentang Penerimaan

Perpajakan.

Waluyo, (2011) Pengertian Penerimaan

Pajak. (Online) diakses dari dictio.id pada

Yeny Kopong, S. E., Ak, C. A., \& Widyaningrum, I. (2016). Pengaruh Reformasi Perpajakan Dan Sosialisasi Perpajakan Terhadap Penerimaan Pajak Dengan Kepatuhan Wajib Pajak Sebagai Variabel Moderating

Pada Kpp Pratama Sunter
Jakarta Utara. Jurnal Vol. 1, No. 2, Jul-Des 2016: 95-106

Yeni Rahma, 2011. Pengaruh Tingkat Kepatuhan Wajib Pajak Badan Terhadap Peningkatan Penerimaan Pajak yang Di Moderasi oleh Pemeriksaan Pajak. Pada KPP PRATAMA PADANG. Vol 1. Nomor 1. Universitas Negeri Padang. 